Meta

Journal des traducteurs

Translators' Journal

\title{
E-lectra: A Bibliography for the Study and Practice of Legal, Court and Official Translation and Interpreting
}

\section{Esther Monzó}

Volume 55, numéro 2, juin 2010

URI : https://id.erudit.org/iderudit/044245ar

DOI : https://doi.org/10.7202/044245ar

Aller au sommaire du numéro

Éditeur(s)

Les Presses de l'Université de Montréal

ISSN

0026-0452 (imprimé)

1492-1421 (numérique)

Découvrir la revue

Citer cet article

Monzó, E. (2010). E-lectra: A Bibliography for the Study and Practice of Legal, Court and Official Translation and Interpreting. Meta, 55(2), 355-373.

https://doi.org/10.7202/044245ar
Résumé de l'article

Le développement scientifique oblige les chercheurs à communiquer efficacement les résultats de leurs travaux. L'augmentation du nombre de revues et de publications académiques dans le monde entier accable les spécialistes et les contraint à se maintenir au courant d'une littérature de plus en plus dispersée. De plus, les professionnels de la traduction juridique doivent trouver et sélectionner la documentation et le matériel de référence spécialisés que le marché n'adresse pas aux traducteurs et interprètes mais aux spécialistes du droit. E-lectra est une base de données bibliographiques électronique qui a pour but d'aider les étudiants et les spécialistes en traduction juridique à repérer les fonds de littérature et de documentation, et d'aider les chercheurs à présenter leurs travaux en leur apportant un réservoir de formats et de styles incorporés dans un système facile à utiliser pour citer des références dans leurs travaux et les adapter aux conventions des différentes revues dans le domaine des études de traduction. 


\title{
E-lectra: A Bibliography for the Study and Practice of Legal, Court and Official Translation and Interpreting
}

\author{
ESTHER MONZÓ \\ Universitat Jaume I, Castelló, Spain \\ monzo.e@gmail.com
}

\begin{abstract}
RÉSUMÉ
Le développement scientifique oblige les chercheurs à communiquer efficacement les résultats de leurs travaux. L'augmentation du nombre de revues et de publications académiques dans le monde entier accable les spécialistes et les contraint à se maintenir au courant d'une littérature de plus en plus dispersée. De plus, les professionnels de la traduction juridique doivent trouver et sélectionner la documentation et le matériel de référence spécialisés que le marché n'adresse pas aux traducteurs et interprètes mais aux spécialistes du droit. E-lectra est une base de données bibliographiques électronique qui a pour but d'aider les étudiants et les spécialistes en traduction juridique à repérer les fonds de littérature et de documentation, et d'aider les chercheurs à présenter leurs travaux en leur apportant un réservoir de formats et de styles incorporés dans un système facile à utiliser pour citer des références dans leurs travaux et les adapter aux conventions des différentes revues dans le domaine des études de traduction.
\end{abstract}

\begin{abstract}
Scientific development presupposes the efficient communication of new findings. The increase in the number of academic journals and publications worldwide burdens scholars, also translation scholars, with the responsibility of keeping up to date with ever increasingly scattered relevant literature. On the other hand, legal translation professionals need to select and find specialised documentation and reference material, which the market addresses not to translators or interpreters but to law specialists. E-lectra is an electronic bibliographic database whose purpose is to help legal translation scholars and practitioners select and find relevant literature and documentation resources, and further help researchers to present their work by providing a powerful pool of formats and styles incorporated in an easy-to-use system for citing references in their works and adapting them to the conventions of different journals from the field of translation studies.
\end{abstract}

\section{MOTS-CLÉS/KEYWORDS}

loi et traduction/interprétation, recherche en traduction/interprétation juridique, documentation, bibliographie

law and translation/interpreting, research on legal translation/interpreting, documentation, bibliography

Many studies on legal translation stress its importance against the scarcity of literature on the subject. Although this was certainly the case only a decade ago, the advances made by both younger and renowned researchers in this branch of the discipline in recent years have brought this claim into question. Nevertheless, there does appear to be a lack of communication among researchers, especially when they use different languages, and insufficient dissemination of literature written in languages other than 
English or, to a lesser extent, French. This limited dissemination is precisely what prompted Navarro Domínguez (1996), a decade ago, and more recently Campos Plaza and Ortega Arjonilla (2005) to compile the scientific production on translation written in Spanish. Initiatives for the German or the Italian language can be traced back to the seventies (van Hoof 1973; Briamonte 1978), as can compilations of English and French works (Bausch, Klegraf et al. 1970, 1972; Delisle and Albert 1979). Franco Aixelá (2003) has also undertaken an enormous project to create a multilingual compilation of works produced within the area of translation and interpretation. The most extensive compilation, however, is to be found in the electronic database Translation Studies Abstracts (Saldanha and Zanettin 1998-), ${ }^{1}$ which requires a subscription for online reference. Another interesting initiative in this line is getCITED (getCITED Inc. 2000), ${ }^{2}$ a free-access online database that relies on voluntary contributions from anyone who wishes to spend their time incorporating new records. Apart from ease of access, the advantages of this system are its excellently designed architecture that allows the user to interconnect and surf the publications, and the fact that it is open to all sorts of works (even in-progress and unpublished works) and all areas of knowledge; on the other hand, the way input is added to the database (dependent on users' good will) leads to an undeniable bias.

All these initiatives are undoubtedly very useful for research and the fact that they are growing in number suggests that they are also felt to be necessary. Nevertheless, both the wide range of objectives set in the initiatives reviewed above and, in some cases, the complexity involved in keeping them up to date, mean that no flexible source is available to researchers where they can find the bibliographical information they require in a centralised and updated form, especially in a growing discipline such as translation studies with so many distinct and varied branches. A number of initiatives have already been implemented with less ambitious objectives. Restricted scope allows for a greater degree of diligence and promptness. Although in an ideal world there should be a centralised database from which we could obtain references and descriptions about works linked to the whole discipline of translation studies (or even access the text itself), the inevitable need to be realistic leads us to appreciate the advantages of decentralisation.

The GITRAD group has been working for several years on a series of initiatives related to this idea in the field of legal, sworn, judicial and official translation and interpreting. Since 1998, when the group was set up, we have been adding bibliographic resources to our website (Monzó and Borja 1998), ${ }^{3}$ which includes a virtual library providing access to whole texts. This has been made possible thanks to contributions from authors who have offered numerous texts on subjects related to the speciality. Other online resources include a catalogue of the resources available at our university; a section with links to other libraries; a bibliography of translation journals; a section about new publications; and a section with references about the speciality the group is working on. Over the years we have built up and improved all these sections, although this paper deals specifically with the final section: a repertoire that has grown from a mere list of useful references for the researcher to what is now intended as a means to meet the challenge of furthering the development of scientific production and emerge as a subject bibliography in its own right, for practitioners and researchers in the field of legal, court, and official translation and interpreting. 


\section{E-lectra: a bibliography}

In Malclès' standard definition (Malclès 1965, 1985), the purpose of a bibliography is to search for, identify, discover, and classify documents with the aim of creating repertoires that make academic work easier. E-lectra is a bibliographic database that includes over 8000 references linked to the interests of the GITRAD group. The core of this bibliography comprises works (books, edited books, special issues of journals, book sections, journal articles, reviews, electronic works, reports, legislation, conference papers, and so forth) that deal with language, translation, and interpreting in fields related to the discipline of law, or which constitute resources for the practice of translation in that field. In addition to this core bibliography, there are also a number of works of different types related to other scientific domains that have been used at various times in the group's research. The bibliography aims to facilitate not only the intellectual task of the specialist researcher, but also that of translators and interpreters working in this area. Indeed this was a determining factor in the decision to include reference works (dictionaries, handbooks, forms and precedents or encyclopaedias) as part of the material.

The initial purpose of E-lectra was simply to provide bibliographic data that could be shared among the members of the group and anybody else who showed a research interest in the same area. The first version of the database, created using one of the earliest versions of the software application EndNote ${ }^{\varpi}$ (and upgraded over the years to reach the current version 12), was set up by the author of this paper as one of her first research projects. Subsequently, this database was to serve as a means of locating the bibliographic references available to the members of the GITRAD team and later still, it has proved to be of great use to students and researchers both for discovering and identifying works of interest and for locating and using them in the activities of translators and those working in translation studies.

The database was only recently named and satisfies a wish to offer the scientific community the proven advantages that E-lectra has already shown in the work carried out by the members of the team and its collaborators. More than simply a pool of bibliographic information that makes it easier for users to obtain essential data for the retrieval of documents by other means, it seeks to make it easier to use the data. An example of how this is achieved is by providing access to bibliographies with the citation formats required by different translation and interpretation journals. Its goal is to disseminate the bibliography not as a hard-copy resource, but as an online electronic resource (hence the $e$-), both as a list of bibliographic references and as a database. At the same time it is intended to be a pool of reading material (lectures, in Catalan - hence, lec) about translation (tra) within the legal field (the le in lec), both for practical and research purposes.

In the following section, I will outline the sources that E-lectra draws on, the types of records it includes, the criteria used for selecting material and the method by which the works are classified. Possible uses of the different versions of the database will be discussed in later sections.

\subsection{Sources}

The sources used in the search for bibliographic material for scientific work are many and varied. Catalogues and databases offer a huge amount of information but con- 
sulting such an assortment of sources requires a great deal of valuable time. In the field of legal translation, several very useful compilations have already been presented that can save the researcher a great deal of costly and sometimes fruitless work (Gémar 1978; Delisle 1987; Mayoral Asensio and Sánchez-Lafuente 1994; Alarcón Navío, López Carrillo, et al. 1996). Nevertheless, in developing E-lectra we deliberately avoided working with these previous bibliographies for ethical reasons, and drawing on our own experience to consult other databases, detailed below, has proved to be sufficient for our goals.

The first reference source consisted of journals in the field of translation. These publications are available at most Spanish universities, and many of them offer index query and bibliographic information distribution services through periodic summaries. One that is particularly interesting and easy to use is Dialnet (Universidad de La Rioja 2001-), ${ }^{4}$ which includes information about $\mathrm{PhD}$ dissertations and is also offered to the members of some Spanish universities as a catalogue. A similar source of information is the abstract database maintained by the Consorci de Biblioteques Universitàries de Catalunya (1996), and also the database of $\mathrm{PhD}$ dissertations hosted at the Catalonia Centre for Supercomputing, with an additional service allowing access to the whole text (Centre de Supercomputació de Catalunya 2000-). ${ }^{5}$ However, these databases neither index the abstracts to allow searches, nor as a rule do they offer full information about the journals. Instead, they restrict their records to those that are actually included in the university collections. Some publishers, however, provide full indices of the journals that they themselves publish. This is the case of John Benjamins, the University of Montreal or Kluwer.

In working with E-lectra, information is extracted from all these sources manually, first, because the absence of search engines impedes automatic selection. Once the papers have been selected, either filters must be constructed ad hoc to import the data gathered, or each record has to be created individually. A more simple method, although it needs post-editing in order to ensure records are homogeneous, is that offered by more elaborate commercial databases, to which the user must subscribe before they can be accessed. Examples of such databases are EJS (EBSCO 1997-), ${ }^{6}$ which includes centralised consulting of several databases, IngentaConnect (Ingenta 2006), ${ }^{7}$ JSTOR (ITHAKA 2000-) ${ }^{8}$ or ISOC (CINDOC 2006), ${ }^{9}$ which covers the Spanish journals on the human and social sciences. These services allow exportation of a file that includes the data on the selected records, and some even prepare a file that enables these records to be imported to other database management systems.

Most catalogues of bibliographic collections allow the user to carry out a less automated search. Despite incorporating a search engine, exporting the selected data must be done manually. Most of these catalogues only index monographs. The TRACES (Castellanos Vila 2006-) ${ }^{10}$ project is an exception and also offers access to journal articles related to the Catalan language and literature. For the case of monographs, some ISBN agency databases (International ISBN Agency 2006) ${ }^{11}$ allow searches to be made for books published in Spain, the United Kingdom, Germany, France, and the United States. The service does not, however, offer export options and processing the data has to be done manually. Neither are similar possibilities offered by other databases that nonetheless include useful information, such as $A B E S$ $\left(\right.$ Clark 1999-) ${ }^{12}$ or online bookshops (Amazon 1996-, Grup Enciclopèdia Catalana 1998). ${ }^{13}$ 
All the sources cited above are offered with languages that any browser can interpret. However, there are catalogues and query utilities that can be consulted, either free of charge or through subscription, from the database management system itself (in our case, EndNote ${ }^{\circledast}$ ). Just a few of the catalogues available are those of the Library of Congress in the USA, the National Library in Portugal, the British Library, the Deutsche Bibliothek, the Universities of Edinburgh, Paris, Alicante, Chicago, Lisbon, Manchester, Montreal or Venice, or the EconLit, Medline or Ovid databases.

As can be seen from the variety of sources involved, the resources indexed in the E-lectra bibliography are limited to a specific subject matter rather than to specific languages. The intention is to offer an international repertoire and, by so doing, include languages that are usually ignored in bibliographic compilations (for example, Galician or Catalan, but also more widely spoken languages such as Italian). The subject matter is not only used to select the works, but also to organise them, as we shall discuss below.

\subsection{Structure and design}

The structure of E-lectra is essentially based on that offered by the management system already used (EndNote ${ }^{\oplus}$, by Thomson), although some changes have been made to meet specific needs. Flexibility is a highly advantageous feature of this system, as it is possible to personalise the type of resources included in the database as well as the fields (their number and type) linked to each kind of bibliographic reference. The adaptation carried out for this bibliography was designed to fit our speciality. Certain types of references, such as maps, are of little use, whereas others that are not provided for in the original structure are of interest both for the discipline as a whole (such as review) and for the thematic speciality (this would be the case of distinguishing between bills and acts of Parliament, for example). The table below shows a list of references finally used in the database together with their quantitative representation in E-lectra.

TABLE 1

Types and numbers of references included in E-lectra

\begin{tabular}{|l|c|}
\hline REFERENCE TYPE & NUMBER OF REFERENCES \\
\hline Book & 2878 \\
\hline Journal Article & 2535 \\
\hline Book Section & 1323 \\
\hline Edited Book & 696 \\
\hline Statute & 292 \\
\hline Dictionary & 239 \\
\hline Review & 152 \\
\hline Thesis & 107 \\
\hline Conference Paper & 98 \\
\hline Report & 74 \\
\hline Electronic Source & 51 \\
\hline Journal/Periodical/Series & 40 \\
\hline
\end{tabular}




\begin{tabular}{|l|c|}
\hline Newspaper Article & 31 \\
\hline Journal (special issue) & 25 \\
\hline Film or Broadcast & 20 \\
\hline Case & 15 \\
\hline Audiovisual Material & 15 \\
\hline Online Database & 15 \\
\hline Computer Program & 8 \\
\hline Bill & 7 \\
\hline Manuscript & 7 \\
\hline Unpublished Work & 5 \\
\hline Magazine Article & 4 \\
\hline Personal Communication & 2 \\
\hline
\end{tabular}

The choice of reference type option affects the fields available when introducing each record. These fields can be further personalised independently for each type of reference. By way of example, I show here the modified structure of the reference types Book, Journal (special issue) (which has been added ex novo to the original management system), Book Section, and Journal Article. Following the table, the fields are also briefly described.

TABLE 2

Fields associated with different record types

\begin{tabular}{|l|l|l|l|}
\hline Book & JouRnAL & Book SECTION & JouRNAL ARTICLE \\
\hline Author & Editor & Author & Author \\
\hline Year & Year & Year & Year \\
\hline Title & Monograph Title & Title & Title \\
\hline Series Editor & & Editor & \\
\hline Series Title & Journal Title & Book Title & Journal \\
\hline City & City & City & City \\
\hline Publisher & & Publisher & \\
\hline Volume & Volume & Volume & Volume \\
\hline Number of Volumes & & Number of Volumes & \\
\hline Series Volume & Issue & Series Volume & Issue \\
\hline Number of Pages & Number of Pages & Pages & Pages \\
\hline & & Series Editor & \\
\hline & & Series Title & Monograph Title \\
\hline Edition & Edition & Edition & Edition \\
\hline & Date & Translator & Date \\
\hline Translator & Translator & Short Title & Translator \\
\hline Short Title & Short Title & Short Title \\
\hline & Alternate Journal Title & & Alternate Journal Title \\
\hline ISBN & ISSN & DSB & ISSN \\
\hline DOI & DOI & Original Publication & Original Publication \\
\hline Original Publication & Original Publication & Reprint Edition \\
\hline Reprint Edition & & Call Number & Call Number \\
\hline Call Number & Call Number & \\
\hline & & & DOI \\
\hline
\end{tabular}




\begin{tabular}{|l|l|l|l|}
\hline Keywords & Keywords & Keywords & Keywords \\
\hline Abstract & Abstract & Abstract & Abstract \\
\hline Notes & Notes & Notes & Notes \\
\hline Research Notes & Research Notes & Research Notes & Research Notes \\
\hline URL & URL & URL & URL \\
\hline Link to PDF & Link to PDF & Link to PDF & Link to PDF \\
\hline Author Address & Author Address & Author Address & Author Address \\
\hline Image & Image & Image & Image \\
\hline Caption & Caption & Caption & Caption \\
\hline Access Date & Access Date & Access Date & Access Date \\
\hline Last Modified Date & Last Modified Date & Last Modified Date & Last Modified Date \\
\hline Translated Author & Translated Author & Translated Author & Translated Author \\
\hline Translated Title & Translated Title & Translated Title & Translated Title \\
\hline Language & Language & Language & Language \\
\hline
\end{tabular}

1) Author/Editor: The name or names of the authors or editors who published the work are inserted in this field. Every time new information is included, the management system updates a table of authors that helps to maintain consistency across all the records, since the program suggests alternatives as we write in the field (thus we can choose to include the same author with two surnames or with one, with the second forename or not, and so forth). To date, the database has a total of 7415 different (personal and institutional) authors indexed. The translation or transliteration of the authors' name can also be included, if necessary, in the field Translated Author;

2) Year: The year the work was published or, in some cases such as journals or collections, the period in which they were (or are) published. For first edition or reprint years, other fields may be used.

3) Title: The title of the publication. Should we wish to include the translation of the title, then we would use the field Translated Title;

4) Series Editor / Editor: In the case of books, this refers to the editor of the collection (who may also be added in a different field in the Book Section reference type); in the case of sections, it refers to the editor of the volume. The editors' names are automatically incorporated into the list of authors;

5) Series Title / Journal Title / Book Title / Journal: In the case of books, the secondary title refers to that of the collection; for special issues of journals, to that of the journal (as opposed to the general title of the monographic issue); in book sections, it refers to the title of the book in which it appears; and if it is a journal article, then it refers to the name of the journal. Journals are incorporated into a table in the database which includes both their full and abbreviated names. At present, this list contains 660 different journals;

6) City: Place of publication;

7) Publisher: Publishing house. The database also keeps a table of all the publishing houses incorporated. It currently includes a total of 1997 publishing houses;

8) Volume: Volume of the journal or book, when they run into several volumes;

9) Number of Volumes: The total number of volumes in the case of books with more than one;

10) Series Volume: In the case of books edited as part of a collection, the number assigned to the book within the collection;

11) Number of Pages / Pages: Paging of papers and chapters or the total number of pages in the case of books and monographic issues of journals;

12) Edition: Number of the edition of the referenced work;

13) Date: In the case of journals that are not numbered by volumes, the publication date (either month or season of the year); 
14) Translator: Translator's name. The names included here are also incorporated automatically into the list of authors mentioned above;

15) Short Title: Abbreviated version of the title, like that used in certain forms of citation employed within the text to distinguish between works by the same author when there are references to several of them;

16) Alternate Title: In the case of journal articles and special issues of periodical publications, the bibliographic references usually appear with the journals' essential designation (Sendebar, rather than Sendebar. Boletín de la Facultad de Traductores e Intérpretes de Granada; or Perspectives, rather than Perspectives: Studies in Translatology). Nevertheless, both names can be linked in the table of journals and then the user can alternate between the two, depending on the requirements of the citation format used by the publication;

17) ISBN/ISSN: Unique number for identifying publications;

18) DOI: Digital Object Identifier. Unique electronic code, similar to $U R L$ or $I S S / B N$, for copyrighted electronic content (International DOI Foundation 2006); ${ }^{14}$

19) Original Publication: Original title of the publication, in the case of translations;

20) Reprint Edition: Reprint number;

21) Call Number: In order to be able to physically locate the work, a code may be added for this purpose;

22) Keywords: Keywords for indexing the work. They are dealt with more thoroughly in the next section;

23) Abstract: Summary of the work;

24) Notes and Research Notes: Annotations of different types. The field Research Notes is especially useful for storing particular quotes from the work in question;

25) URL (Uniform Resource Locator): Web address that is saved as a hyperlink;

26) Link to PDF: In the case of PDF files stored locally, the file path. The file may be easily recovered after the link is established;

27) Author Address: The author's address or the institution he or she is associated with;

28) Image: Graph or any other type of image included in the work;

29) Caption: Brief description of the image from the previous field;

30) Access Date / Last Modified Date: It is advisable to make a note of the date an electronic resource was accessed or last updated;

31) Translated Author / Translated Title: When working with different languages, it can be worth using one of them to translate titles into other languages or to transliterate people's names whenever necessary;

32) Language: Mention of the language the work is written in.

Many of the fields are left blank when the references are introduced. The ones that have been deliberately filled in are those that allow a synthetic bibliography to be produced (in the case of books, Author, Year, Title, City, and Edition, as well as Translator in the case of translated works and where appropriate, Edition, Number of Volumes, Volume, or URL) and indexing (Keywords). Yet it is possible to establish a sub-corpus consisting of a descriptive-type bibliography (526 references include an abstract and 1818 references include research notes). The screenshot below shows how a database record is edited: 
FIGURE 1

Bibliographic record editing window in EndNote

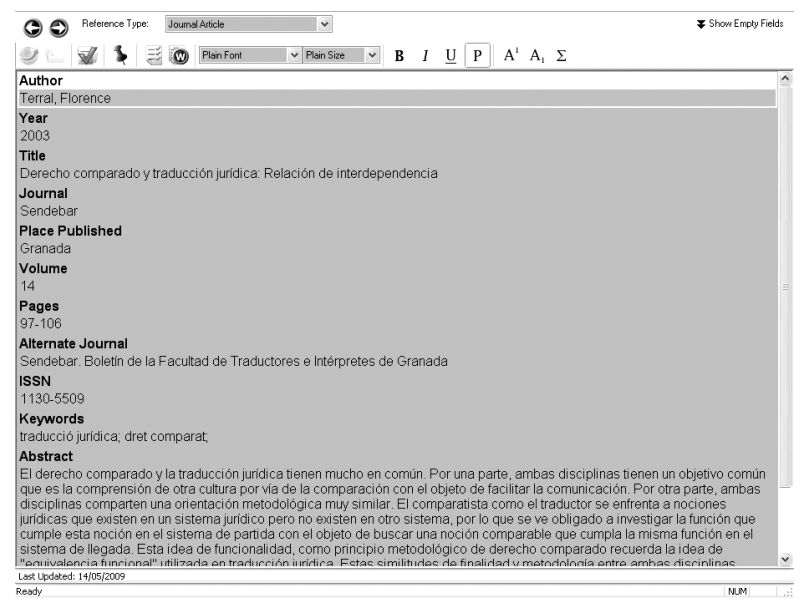

\subsection{Selection and classification}

The aim of E-lectra is to gather works on translation and interpreting in the legal and institutional fields. The bibliography, therefore, is not limited to works in a single language combination, and includes references to works in Spanish, Catalan, English, French, German, and, although less frequently, Portuguese, Galician, Italian, and Basque. Because the most important journals in this area tend to require the use of English and French, they enjoy a higher degree of diffusion and are undoubtedly the predominant languages in our database. Nevertheless, it should be noted that in this specialised field of knowledge, the minority languages also produce very interesting resources, especially when their official status is relatively recent, because the translation of texts between the dominant and dominated languages is common practice in these cases. Our own limitations have, however, made it impossible to include a greater number of languages.

The characteristic multidisciplinarity of translation studies research is also evident in the database, which includes works from related subjects and disciplines to complement the core references. Although the connecting thread is legal translation, this does not mean there is no room for other translation specialisations and works from other disciplines (law, linguistics, sociology or psychology) that are so often interwoven in the research carried out in translation studies. Neither did we have any desire to restrict the contents to research works, since our intention was to provide a useful tool for both the professional translator and the researcher. As a result, the number of manuals and reference materials included in the database, as well as publications dealing with a range of matters from the discipline of law, has increased notably.

Keywords representing the content of the documents are used to organise the references. Free language was chosen for this indexing owing to the terminological fluctuations that still take place within our field (Gambier and van Doorslaer 2007). The level of detail of these keywords was deliberately reduced in order to ensure the 
efficiency of the queries, and bearing in mind the many disciplines that translators and researchers in this speciality have to work with. The total number of keywords used is 742 . By way of example, we have included those linked to the field of translation studies:

\section{TABLE 3}

Keywords linked to the field of translation studies used in E-lectra

\begin{tabular}{|l|}
\hline Legal translation \\
Sworn translation \\
Official translation \\
Court translation \\
Legislative translation \\
Administrative translation \\
Economic translation \\
Commercial translation \\
\hline Audiovisual translation \\
Technical translation \\
Scientific translation \\
Literary translation \\
Bible translation \\
Localisation \\
Journalist translation \\
Advertising translation \\
Medical translation \\
\hline Book translation \\
Specialised translation \\
\hline Translation theory \\
Psycho-translation \\
Socio-translation \\
Translation linguistics \\
History of translation \\
\hline Translation methodology \\
\hline
\end{tabular}

\begin{tabular}{|c|}
\hline $\begin{array}{l}\text { Legal interpreting } \\
\text { Sworn interpreting } \\
\text { Official interpreting } \\
\text { Court interpreting } \\
\text { Community interpreting }\end{array}$ \\
\hline $\begin{array}{l}\text { Interpreting } \\
\text { Sight interpreting } \\
\text { Conference interpreting } \\
\text { Simultaneous interpreting } \\
\text { Sign language interpreting } \\
\text { Phone interpreting }\end{array}$ \\
\hline $\begin{array}{l}\text { Machine translation } \\
\text { Translation practice } \\
\text { Translation training } \\
\text { Translation technologies }\end{array}$ \\
\hline
\end{tabular}

The following list shows the main branches of our bibliography without breaking it down further into subdivisions:

1) Translation studies

2) Law

3) Economics

4) Linguistics

5) Sociology

6) Psychology

7) Other disciplines

In addition to this thematic classification, a note is also made of the geographical location the work focuses on (which allows us to distinguish between a Spanish and a Chilean law dictionary, for example); the type of work, in order to differentiate between dictionaries, bibliographies, forms or manuals; and the language, in the case of both the language the work was written in and the dictionaries or works used in translation studies that involve one or several pairs of languages. 


\section{Possibilities E-lectra offers}

The ways in which E-lectra can help its users largely depends on the version of the bibliography they have. As a bibliographic repertoire, the information is offered as a list and is therefore static, although it is constantly being updated. As a database, users must have the EndNote $e^{\circledast}$ management system or software with similar characteristics installed on their computer; it can then be utilised to obtain the same information, add or update records or used as an aid in producing written work.

\subsection{Bibliographic repertoire}

The version available from the group's website is the result of a standard query which selects the works that match any of the keywords and arranges them under the following headings:

1) Legal translation

2) Sworn translation

3) Court translation

4) Official translation

5) Legislative translation

6) Administrative translation

7) Economic translation

8) Commercial translation

9) Court interpreting

10) Sworn interpreting

11) Official interpreting

12) Legal language

13) Judicial language

14) Legislative language

15) Administrative language

16) Economic language

The result of this search is provided on the website as a bibliographic repertoire intended for researchers. The search result aimed at professional translators appears after a query that combines types of resource (dictionaries, forms, and handbooks) with a basic thematic restraint (law and economics).

In the first case, and in an attempt to facilitate academic work, we sought to offer bibliographic citation formats that match those used in the most widely read translation journals. We did not consider it necessary to repeat the same process in the case of reference material. As an example, an appendix has been included containing a sample list of references formatted according to Meta's styles.

The option to alternating between different citation formats arose from the work done on producing suitable templates. Although the management system already provides templates that can be used with a wide range of publications, the area of translation and interpretation is not represented at all in any of the commercial templates. Indeed, only 15 of the publications on studying language appear among the 2500+ templates available. The development of E-lectra has led to the creation of another 15 templates to date, specifically for the scientific field of translation. Designing these templates is a very complex task, since the changes among formats must be reflected in each of the different types of reference (journal article, book 
section, book, edited book, case, and so forth) and this demands that specifications be provided in each template for most of them. The screenshot below shows, as an example, some of the details from the template for the journal Hermeneus (Zarandona 1999-). ${ }^{15}$

\section{FIGURE 2}

Sample of the design of the template Hermeneus for the citation format

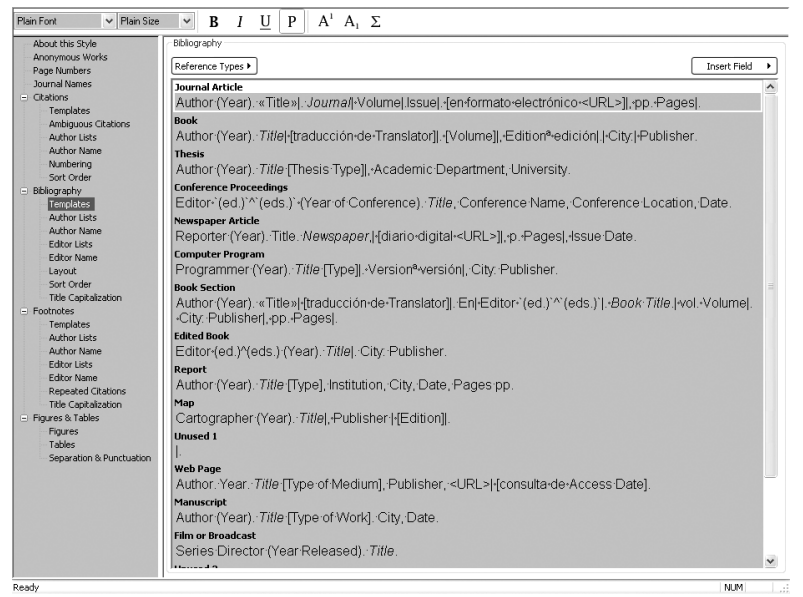

\subsection{Automatic bibliographies}

A second way to use E-lectra is by acquiring the database itself. The first advantage is that it allows searches for references on the subject matter worked on. They can thus be located and, in some cases, accessed if the user has the right to use databases such as EJS (mentioned above). Once they have been consulted, these references are available for inclusion in any work without having to collect the data that make up the reference.

In addition to the benefits of having a warehouse of references, there are also advantages affecting their administration. Thanks to the possibilities offered by the management system, E-lectra can be used in the production of research works to ensure homogeneity of formats in the citations and bibliographic references. When the program is installed, a plug-in is incorporated into the word processor that allows us to work with the database while writing the text. Thus, when we want to include a reference, all we need to do is select the work in E-lectra and a brief citation (author and year) will be incorporated into the text at the point where it is to appear and at the same time the full reference will be included at the end of the document. Both references will match the format of the selected journal.

This process brings consistency to the written piece and also saves the researcher time, since he or she does not have to worry about forgetting any of the cited references or about matching the bibliography of different works to the various journals' requirements. 


\section{Extract of references on legal, sworn, and official translation}

In this section, I present an extract of the references included in the database that concern legal, sworn or official translation. This bibliography is intended merely as an example of the contents of E-lectra. Because these contents are continually being updated and these studies are presently enjoying a good state of health, they are not particularly well suited to being set down in print, as such a version would quickly become obsolete.

For the sake of brevity, the bibliography that appears in the appendix only includes monographic publications (books, edited books, and special issues of journals) that match the keywords legal translation, sworn translation or official translation. Employing the same keywords but without restricting the search by type of publication would have added another 645 references to the 71 works that already appear in the list (totalling 716).

The following table shows a list of the works indexed with a greater range of keywords linked to translation and without restricting the search by type of publication.

TABLE 4

Record of the works indexed with the respective keywords (translation)

\begin{tabular}{|l|c||l|c|}
\hline KEYWORD & NO. OF WORKS & KEYWORD & No. OF WORKS \\
\hline Legal translation & 552 & Economic translation & 25 \\
\hline Sworn translation & 169 & Administrative translation & 9 \\
\hline Official translation & 46 & Commercial translation & 2 \\
\hline Court translation & 33 & & \\
\hline Legislative translation & 14 & & \\
\hline
\end{tabular}

To cover other fields of interest, we offer a list of works on interpreting specialities and on language studies associated with legal translation.

TABLE 5

Record of the works indexed with the respective keywords (interpreting and language)

\begin{tabular}{|l|c||l|c|}
\hline KEYWORD & No. OF WORKS & KEYWORD & No. OF WORKS \\
\hline Court interpreting & 301 & Legal language & 398 \\
\hline Sworn interpreting & 41 & Judicial language & 60 \\
\hline Legal interpreting & 26 & Administrative language & 51 \\
\hline Official interpreting & 19 & Legislative language & 24 \\
\hline & & Economic language & 12 \\
\hline
\end{tabular}

\subsection{General trends in the bibliography}

Several trends can be identified from the bibliography included in E-lectra. For instance, there are a relatively large number of publications deriving from congresses and works produced for educational purposes. This could be a consequence of the novelty of the discipline and the recent academic interest in specialised forms of translation other than literary translation. It is also worth noting that works in Spanish appeared relatively late as far as Spain is concerned, but in Argentina sworn, or public, translation has been the subject of a good many reflections published since 
the fifties. In the seventies, French was the dominant language, with authors centred in Montreal. In the middle and late eighties, monographic works were published in English and German and a notable increase in the number of works in Spanish occurred in the last century. Works in Catalan proliferated from the eighties onwards and their diffusion was largely made possible thanks to the Revista de Llengua i Dret (Milian i Massana, Vernet i Llobet, et al. 1983-). ${ }^{16}$

In terms of subject matter (in relation to legal translation and interpreting), sworn translation ranks highly among the works written in Spanish and official translation is the predominant subject in Catalan, Galician and Basque, as well as in works by authors who publish in other languages but who refer to the situation of those languages in their writings. The problems of translation and textual analyses are predominant in English, and in French there are more works that examine the theoretical aspects of the cultural transfer involved in translating law. There is a relative scarcity of those topics in the bibliography written in Spanish and in languages with a lower degree of diffusion. Professional matters are a predominant concern in the USA, where court translation and interpreting is widely dealt with, and Spanish-speaking regions, where a great deal of attention is paid to sworn translation. Among the works written in Portuguese and Italian we find a relative scarcity of studies devoted to the field. In fact, there are more studies about Italian legal and economic texts written by Spanish authors than those published in Italian works.

\section{Final reflections}

The fact that we were able to compile a list of 712 research works devoted specifically to translation in the legal field and 368 more dealing with interpreting in this same area shows that there is considerable interest in this field of study. Including them altogether in a single database is also very convenient for the researcher, who not only can use them, but can also discover their existence, especially in the case of less widespread languages. The possibility of accessing the whole text in some cases, often with a subscription to a commercial publication collection system, is an added advantage that the GITRAD group hopes to promote in the future development of E-lectra.

Moreover, designing templates to facilitate the automatic formatting of references in accordance with journal or publishing house requirements in a steadily growing area such as ours is an initiative that attempts to fill a gap left by the companies that market bibliographic data management applications because they do not consider it to be sufficiently cost-effective. At the same time, it provides a way for researchers to considerably increase their productivity, since they need to pay less attention to aspects of format and are free to focus more on the intellectual activity in hand.

The professional working in this speciality can also derive important benefits from a bibliography of this type, because centralising references and sorting them by topics allows the practising translator to discover and later locate handbooks, forms, dictionaries, and glossaries that can be a valuable aid in his or her daily labours.

In sum, E-lectra has been designed as a further tool to help translators and researchers in translation studies who specialise in the field of law, and also as a privileged tool for analysing the evolution of research in the field. 


\section{NOTES}

1. Saldanha, Gabriela and Zanettin, Federico, eds. (1998-): Translation studies abstracts. Bibliography of Translation Studies. Visited 23 October 2009, <http://www.stjerome.co.uk/tsaonline/>.

2. GetCITED Inc., ed. (2000-): GetCITED. Visited 23 October 2009, <http://www.getcited.org/>.

3. Monzó, Esther and BorJA, Anabel, ed. (1998): GITRAD. Web del Traductor Jurídic / Web del Traductor Jurídico / The Legal Translator's Webpage. Visited 23 October 2009, <http://www.gitrad. uji.es/>.

4. Universidad de La Rioja, ed. (2001-): Dialnet: Servicio de alertas y hemeroteca virtual de sumarios de revistas científicas españolas. Visited 23 October 2009, <http://dialnet.unirioja.es/>.

5. Consorci de Biblioteques Universitàries de Catalunya, ed. (26 January 2004): Base de dades de sumaris. Visited 23 October 2009, <http://sumaris.cbuc.es/>.

6. EBSCO, ed. (1997-): Electronic Journals Service. Visited 23 October 2009, <http://ejournals.ebsco. $\mathrm{com} />$.

7. Ingenta, ed. (2006): IngentaConnect. Visited 23 October 2009, <http://www.ingentaconnect. $\mathrm{com} / \mathrm{s}$.

8. ITHAKA, ed. (2000-): JSTOR. The Scholarly Journal Archive. Visited 23 October 2009, <http://www. jstor.org/>.

9. CINDOC, ed. (2006): ISOC. Revistas españolas de ciencias humanas y sociales. Visited 19 March 2010, <http://bddoc.csic.es:8085/index.jsp >.

10. Castellanos Vila, Jordi, ed. (2006-): TRACES. Llengua i literatura catalanes. Universitat Autònoma de Barcelona. Visited 22 October 2009, <http://www.traces.uab.es/tracesbd/>.

11. International ISBN Agency, ed. (2006): International ISBN Agency. Visited 23 October 2009, $<\mathrm{http} / / /$ www.isbn-international.org/en/agencies.html $>$.

12. Clark, R. (1999-): Abes. Annotated Bibliography for English Studies, Visited 23 October 2009, $<$ https://www.routledgeabes.com/sabe/home $>$.

13. Grup Enciclopèdia Catalana, ed. (1998): Llibres.cat. Visited 23 October 2009, <http://www.llibres. cat>.

Amazon.com (1996-): Amazon. Visited 23 October 2009, <http://www.amazon.com>.

Centre de Supercomputació de Catalunya (CESCA), ed. (2000-): Tesis doctorals en xarxa. Visited 23 October 2009, <http://www.tdx.cesca.es/>.

14. International DOI Foundation, ed. (2006): The DOI ${ }^{\circ}$ System. The DOI ${ }^{\circ}$ Handbook. Visited 23 October 2009, <http://www.doi.org/hb.html $>$.

15. Zarandona, Juan Miguel, ed. (1999-): Hermeneus. Revista de Traducción e Interpretación. Soria: Universidad de Valladolid.

16. Milian i Massana, Antoni, Vernet i Llobet, Jaume, and Mirambell, Antoni, eds. (1983-): Revista de Llengua i Dret. Barcelona: Escola d'Administració Pública de Catalunya.

\section{REFERENCES}

Alarcón Navío, Esperanza, López Carrillo, Rodrigo, and Ortega Arjonilla, Emilio (1996): Repertorio bibliográfico general sobre traducción jurídica y jurada dentro de la combinación lingüística francés-español. In: Pedro San Ginés Aguilar and Emilio Ortega Arjonilla, eds. Introducción a la traducción jurídica y jurada (francés-español). Granada: Comares, 347-354.

BAUSCH, Karl-Richard, KLEgRAF, Josef and Wilss, Wolfram (1970): The Science of Translation: An Analytical Bibliography. Vol. 1 (1962-1969). Tübingen: Tübinger Beiträge zur Linguistik.

BAUSCH, Karl-Richard, KLEGRAF, Josef and Wilss, Wolfram (1972): The Science of Translation: An Analytical Bibliography. Vol. 2 (1970-1971). Tübingen: Tübinger Beiträge zur Linguistik.

Briamonte, Nino (1978): Bibliografia sui problemi storici, teorici e pratici della traduzione. Venice: Università Ca' Foscari.

Campos Plaza, Nicolas and Ortega Arjonilla, Emilio (2005): Panorama de lingüística y traductología. Traducción en el Atrio. Vol. 8. Granada: Atrio.

Clark, Robert, ed. (1999-): ABES. Annotated Bibliography for English Studies. Norwich: Swets and Zeitlinger.

Delisle, Jean and Albert, Lorraine (1979): Guide bibliographique du traducteur, rédacteur et terminologue / Bibliographic guide for translators, writers and terminologists. Cahiers de traductologie. No 1. Ottawa: Éditions de l'Université d'Ottawa. 
Delisle, Jean (1987): Bibliographie du traducteur / Translator's bibliography. Ottawa: Presses de l'Université d'Ottawa.

Franco Aixelá, Javier (2003): BITRA: An International On-Line Bibliography of Interpreting and Translation Studies. Babel. 49(2):149-163.

Gambier, Yves and van Doorslaer, Luc, eds. (2007): The Metalanguage of Translation. Target. 19(2).

GÉmAR, Jean-Claude (1978): Droit et justice. Bibliographie sélective du traducteur. Montreal: Linguatech.

MALCLÈs, Louise-Noëlle (1965): Les sources du travail bibliographique. Bibliographies spécialisées (sciences exactes et techniques). Vol. 3. Geneva: Droz.

MalClÈs, Louise-Noëlle (1985): Manuel de bibliographie. Paris: PUF.

Mayoral Asensio, Roberto and Sánchez-Lafuente, José Luis (1994): Bibliografía de la traducción jurada (inglés-español). Sendebar. 5:327-338.

Navarro Domínguez, Fernando (1996): Manual de bibliografía española de traducción e interpretación. Diez años de historia, 1985-1995. Alicante: Universidad de Alicante.

van Hoof, Henri (1973): Internationale Bibliographie der Übersetzung / International bibliography of translation. Pullach bei München: Verlag Dokumentation.

\section{APPENDIX}

List of monographs (books, edited books, and monographic issues of journals)

Aguirre, Angela M., ed. (1990): Proceedings of the Northeast Conference on Legal Interpretation and Translation. Jersey: Consortium on Legal Interpretation and Translation.

Alcaraz Varó, Enrique (1994): El inglés jurídico. Textos y documentos. Barcelona: Ariel.

Alcaraz Varó, Enrique (2000): El Jurista como traductor y el traductor como jurista. Lliçó inaugural del curs acadèmic 2000-2001. Barcelona: Universitat Pompeu Fabra.

Alcaraz Varó, Enrique, Campos, Miguel Ángel, and Miguélez, Cynthia (2001): El inglés jurídico norteamericano. Barcelona: Ariel.

Alcaraz Varó, Enrique and Hughes, Brian (2002): Legal Translation Explained. Manchester: St. Jerome.

Álvarez Calleja, M. Antonia (1991): Estudios de traducción (inglés-español): teoría, práctica, aplicaciones. Cuadernos de la UNED. Vol. 96. Madrid: Universidad Nacional de Educación a Distancia.

Álvarez Calleja, M. Antonia (1995): Traducción jurídica inglés-español. Madrid: Universidad Nacional de Educación a Distancia.

Aranguez Sánchez, Carlos and Alarcón Navio, Esperanza (2000): El Código Penal francés. Traducido y anotado. Granada: Comares.

Arnaud, Vicente Guillermo (1958): Historia y legislación de la profesión de traductor público. Buenos Aires.

BAILey, Catherine J. (1967): Manual del traductor público. Buenos Aires.

Bauer-Bernet, Hélène (1983): Droit, informatique et traduction: l'expérience de la Communauté économique européenne: la puce et le dragon à sept langues. Québec: Conseil de la langue française.

Bocquet, Claude (1994): Pour une méthode de traduction juridique. Prilly: CB.

Borja AlBI, Anabel (2000): El texto jurídico inglés y su traducción al español. Barcelona: Ariel. BoRJa AlBi, Anabel (2007): Estrategias, materiales y recursos para la traducción jurídica. Madrid: Edelsa.

BoRn, Joachim and SchÜTTE, Wilfried (1995): Eurotexte. Textarbeit in einer Institution der EG. Studien zur deutschen Sprache. Vol. 1. Tübingen: Narr.

Buckley, Ron, Hatim, Basil, and Shunnaq, Abdulla (1995): The Legal Translator at Work: Arabic-English Legal Translation. A Practical Guide. Irbid (Jordan): Dar Al-Hilal for translation and publishing. 
Chromá, Marta (2004): Legal Translation and the Dictionary. Lexicographica, Series maior. Vol. 122. Tübingen: Niemeyer.

Corpas Pastor, Gloria, ed. (2003): Recursos documentales y tecnológicos para la traducción del discurso jurídico (español, alemán, inglés, italiano, árabe). Granada: Comares.

Corsellis, Ann (1995): Non-English Speakers and the English Legal System: A Handbook to Good Practice for Those Working in the Legal System Across Language and Culture. Cropwood Occasional Paper. Vol. 20. Cambridge: University of Cambridge.

Elena García, Pilar (2001): La traducción de documentos alemanes. Traducción jurada. Granada: Comares.

ESIT, ed. (1999): Dossier 10. La traduction juridique et assermentée. Special issue of Point Com. Bulletin en ligne de l'Association des Anciens Elèves de l'Ecole Supérieure d'Interprètes et de Traducteurs de l'Université de Paris. Visited 19 October 2009, <http://www.geocities.com/ aaeesit/juri1.html>.

Esteves-Ferreira, João, ed. (1998): équivalences 98. ASTTI Seminar 25.9.1998. Séminaire ASTTI (Bern). Bern: ASTTI. Visited 19 October 2009, <http://www.tradulex.org/Actes1998/sommaire.htm>.

Feria García, Manuel C., ed. (1999): Traducir para la justicia. Granada: Comares.

Garre, Marianne (1999): Human Rights in Translation. Legal Concepts in Different Languages. Copenhagen: Copenhagen Business School Press.

GÉMAR, Jean-Claude (1978): Droit et justice. Bibliographie sélective du traducteur. Montreal: Linguatech.

GÉmAR, Jean-Claude, ed. (1979): La traduction juridique. Special issue of Meta. 24(1).

GÉmAR, Jean-Claude, ed. (1982): Langage du droit et traduction: essai de jurilinguistique. The Language of the Law and Translation. Essays on Jurilinguistics. Montreal: Linguatech/Conseil de la langue française.

GÉMAR, Jean-Claude (1987): TRA 3100, traduction juridique et administrative: plan du cours, recueil de lectures, notes d'orientation et textes. Montreal: Librairie de l'Université de Montréal.

GÉmAR, Jean-Claude (1991): Traduction juridique et administrative. Plan du cours, recueil de lectures, notes d'orientation et textes. Montreal: Librairie de l'Université de Montréal.

GÉMAR, Jean-Claude (1995): Traduire ou l'art d'interpréter. Langue, droit et société: éléments de jurilinguistique. Tome 2: Application. Sainte-Foy: Presses de l'Université du Québec.

GÉMAR, Jean-Claude (1996): Traduire ou l'art d'interpréter: fonctions, statut et esthétique de la traduction, Tome I: Principes.

GÉMAR, Jean-Claude (1996): Traduire ou l'art d'interpréter: Langue, droit et société: éléments de jurilinguistique. Tome II: Application, Sainte-Foy: Presses de l’Université du Québec.

GémAR, Jean-Claude and KASIRER, Nicholas, eds. (2005): Jurilinguistique: entre langues et droits. Jurilinguistics: Between Law and Language. Montreal: Thémis.

González Ruiz, Víctor M. (2004): La traducción clara de lo jurídico: textos de trabajo. Las Palmas: Universidad de Las Palmas de Gran Canaria.

GREJUT (2000): La Traduction Juridique. Histoire, théorie(s) et pratique / Legal Translation. History, Theory/ies and Practice (Geneva, 17-19 February 2000). Geneva: University of Geneva. Visited 22 October 2009, <http://www.tradulex.org/Actes2000/sommaire.htm>.

De Groot, Gérard-René and Schulze, Reiner, eds. (1999): Recht und Übersetzen. Baden-Baden: Nomos.

Houbert, Frédéric (2005): Guide pratique de la traduction juridique: français/anglais. Paris: La Maison du Dictionnaire.

IORIATti Ferrari, Elena, ed. (2007): La traduzione del diritto comunitario ed europeo: riflessioni metodologiche. Atti del Convegno. (Trento, 10-11 March 2006). Trento: Università di Trento.

Losada Liniers, Teresa (2003): La traducción jurídica: didáctica y aspectos textuales. Pozuelo: Losada. 
MÁrQuez Villegas, Luis (2003): Formulario de traducciones juradas: francés-español y españolfrancés. Valencia: CVS.

Mayoral Asensio, Roberto (2003): Translating Official Documents. Manchester: St. Jerome.

Monzó, Esther, ed. (2005): Noves recerques en traducció jurídica. Special issue of Papers Lextra. 1. Visited 22 October 2009, < http://www.lextra.uji.es/papers/2005/lextra2005.pdf>.

Monzó, Esther and BorJA Albi, Anabel, eds. (2005): La traducción y la interpretación en las relaciones jurídicas internacionales. Castellón de la Plana: Universitat Jaume I.

Monzó, Esther, ed. (2006): Les plomes de la justícia. La traducció al català dels textos jurídics. Barcelona: Pòrtic.

Morris, Marshall, ed. (1995): Translation and the Law, American Translators Association Scholarly Monograph Series. Philadelphia: John Benjamins.

Orozco Jutorán, Mariana and Sánchez-Gijón, Pilar, eds. (2006): Didàctica i gestió de la terminologia jurídica. Special issue of Papers Lextra. 2. Visited 22 October 2009, <http:// www.lextra.uji.es/papers/2006/lextra2006.pdf>.

Pelage, Jacques (2001): Éléments de traductologie juridique, application aux langues romanes. Paris: J. Pelage.

Plassard, Freddie, ed. (2006): Jeux de Lois. Special issue of Traduire. 208.

Pommer, Sieglinde (2006): Rechtsübersetzung und Rechtsvergleichung. Translatologische Fragen zur Interdisziplinarität. Frankfurt am Main: Peter Lang.

San Ginés Aguilar, Pedro and Ortega Arjonilla, Emilio, eds. (1996): Introducción a la traducción jurídica y jurada (inglés-español). Granada: Comares.

San Ginés Aguilar, Pedro and Ortega Arjonilla, Emilio, eds. (1996): Introducción a la traducción jurídica y jurada (francés-español). Granada: Comares.

SANDRINI, Peter, ed. (1999): Übersetzen von Rechtstexten. Tübingen: Narr.

ŠARČEviČ, Susan (1997): New Approach to Legal Translation. The Hague: Kluwer Law International.

ŠA RČEviČ, Susan, ed. (2001): Legal Translation: Preparation for Accession to the European Union. Rijeka: University of Rijeka.

Schena, Leandro and Snel-Trampus, Rita D., eds. (2002): Traduttori e giuristi a confronto. Interpretazione traducente e comparazione del discorso giuridico. Bologna: CLUEB.

Schreiber Publishing (2001): Translator Self-Training. Spanish-Legal. A Practical Course in Technical Translation, Rockville: Schreiber.

SсHWAB, Wallace, ed. (2002): Traduction et terminologie juridiques / Legal translation and terminology. Special issue of Meta. 47(2).

Snel-Trampus, Rita D. (1989): La traduzione e i linguaggi giuridici olandese e italiano - Aspetti e problemi. Trieste: Italo Svevo.

SNOw, Gérard and VANDERLINDEn, Jacques (1995): Français juridique et science du droit: textes présentés au deuxième colloque international du Centre international de la common law en français (CICLEF). (Moncton, 24 September 1993). Brussels: Bruylant.

Sofer, Morry (2004): Translator Self-Training Program, Spanish Legal: A Practical Course in Technical Translation. Rockville: Schreiber.

Stoll, Nicole, ed. (1998): La traduction juridique. Special issue of Hieronymus. 3. Visited 22 October 2009, <http://www.tradulex.org/Hieronymus/Hiero-content.htm>. Bern: ASTTI.

TAYLER, Marilyn R. (1985): Skills for bilingual legal personnel: translating, interpreting, and cultural fluency = Técnicas para el personal bilingüe en el área legal: traducción, interpretación y penetración cultural. Glenview: Scott, Foresman and Co.

Tedaldi, Carmela, ed. (2003): La traduction juridique / La traduzione giuridica. Special issue of Hieronymus. 1. Visited 22 October 2009, <http://www.tradulex.org/Hieronymus/Hierocontent.htm>. Bern: ASTTI.

Tomaszczyк, Jerzy, ed. (1999): Aspects of Legal Language and Legal Translation. Lódz: Lódz University Press.

Ugarte, Xus, ed. (2007): I Jornada sobre Dret i Traducció. Special issue of Papers Lextra. 3. Visited 22 October 2009, <http://www.lextra.uji.es/papers/2007/lextra2007.pdf>. 
WAGNER, Emma, Bech, Svend, and Martínez, Jesús M. (2002): Translating for the European Union Institutions. Manchester: St. Jerome.

WAY, Catherine, ed. (2002): La traducción jurídica. Special issue of Puentes. Hacia nuevas investigaciones en la mediación intercultural. 2.

WeIsflog, Walter E. (1987): Rechtsvergleichung und juristische Übersetzung. Eine interdisziplinäre Studie. Zurich: Schulthess.

White, James (1990): Justice as Translation: An Essay in Cultural and Legal Criticism. Chicago: University of Chicago Press.

Wiesmann, Eva (2004): Rechtsübersetzung und Hilfsmittel zur Translation. Wissenschaftliche Grundlagen und computergestützte Umsetzung eines lexikographischen Konzepts. Forum für Fachsprachenforschung. Vol. 65. Tübingen: Narr.

Witthaus, Rodolfo E., Voglino, Mónica, Hernández, Angela, et al. (2000): Régimen legal de la traducción y del traductor público. Buenos Aires: Abeledo-Perrot.

ZACCARIA, Giuseppe, ed. (2000): Übersetzung im Recht / Translation in Law. Münster: LIT. 